\title{
Cianobacterial bloom and animal mass mortality in a reservoir from Central Argentina
}

\author{
Mancini, M. ${ }^{\mathrm{a}}$, Rodriguez, $C .^{\mathrm{a} *}$, Bagnis, G. $^{\mathrm{a}}$, Liendo, $A .^{\mathrm{b}}$, \\ Prosperi, C. ${ }^{\mathrm{c}}$, Bonansea, $M .{ }^{\mathrm{a}}$ and Tundisi, $J G .^{\mathrm{d}}$ \\ aFacultad Agronomía y Veterinaria, Universidad Nacional de Río Cuarto, \\ Ruta Nac. 36 Km 601, CP 5800, Río Cuarto, Argentina \\ ${ }^{\mathrm{b}}$ Municipalidad de Almafuerte, Gestión Ambiental, Universidad Blas Pascal, \\ Donato Alvarez 380, CP 5000, Córdoba, Argentina \\ 'Gestión Ambiental, Universidad Blas Pascal, Municipalidad de Almafuerte, \\ Tucumán 777, CP 5854, Almafuerte, Argentina \\ dInstituto Internacional de Ecologia - IIE, Rua Bento Carlos, 750, CEP 13560-660, São Carlos, SP, Brazil \\ *e-mail: crodriguez@ayv.unrc.edu.ar \\ Received January 8, 2010 - Accepted June 5, 2010 - Distributed October 31, 2010
}

(With 4 figures)

\begin{abstract}
Piedras Moras reservoir ( $32^{\circ} 10^{\prime} 27^{\prime \prime} \mathrm{S}$ and $64^{\circ} 16^{\prime} 29^{\prime \prime} \mathrm{W} ; 832$ ha), integrates a series of artificial lakes belonging to the Rio Tercero basin (Córdoba, Argentina). During March 2009 an algal bloom occurred, coinciding with several animal species mortality, mainly wild birds. The goal of this work was to establish the trophic status of the reservoir in relation to that mortality. Variables were evaluated in situ (temperature and water transparency) and samples were taken in order to identify algal species, Chl- $a$ concentration (spectrophotometry) and toxins - total microcystines(inmuno-enzymatic assay, ELISA). Histopathology studies were made on Fulica sp. A strong heterogenity in water transparency was observed, and "patches" of Potamogeton berteroanus distributed all along the lake, with Secchi disk minimal and medium values of 0.15 and $0.94 \mathrm{~m}$. Chl- $a$ concentration oscillated from 35.7 to $320.9 \mathrm{mg} . \mathrm{m}^{-3}$. Predominant phytoplankton species were Anabaena spiroides and Microcystis aeruginosa (Cyanophyceae). Water temperature was $27.8^{\circ} \mathrm{C}( \pm 0.88)$. Maximal value of total microcystine concentration was $0.23 \mu \mathrm{g} . \mathrm{L}^{-1}$. Chl- $a$ concentration at the moment when mass mortality occurred $\left(2.022 \mathrm{mg} . \mathrm{m}^{-3}\right)$, and histopathological observations, strongly suggest that the animals' death was due to cianotoxins.
\end{abstract}

Keywords: reservoirs, eutrophication, cianobacteria, mass mortality, birds.

\section{Florescimento de cianobactérias e mortalidade em massa de animais em um reservatório da Argentina Central}

\begin{abstract}
Resumo
O reservatório de Piedras Moras (32 10’27” S e 64 16’29” W; 832 ha) faz parte de uma série de lagos artificiais que estão localizados na bacia do rio Tercero (Córdoba, Argentina). Durante março de 2009, ocorreu um florescimento maciço de cianobactérias que resultou na morte de muitas espécies de animais, especialmente aves aquáticas silvestres. O objetivo deste trabalho foi o de estabelecer o estado trófico do reservatório em função desta mortalidade. As variáveis foram avaliadas in situ (temperatura e transparência da água). Foram coletadas amostras para analisar as espécies de algas encontradas nos florescimentos. Foram determinados chl-a (espectrofotometria) e toxinas (microcistinas totais ensaio imunoenzimático ELISA). Estudos histopalógicos foram realizados em Fulica sp. Uma grande heterogeneidade em transparência de água foi observada e agrupamentos de Potamogeton berteroanus estavam distribuídos em todo o reservatório com valores mínimos e médios do disco de Secchi de 0,15 a 0,54 m. Concentrações de chl- $a$ oscilaram de 35,7 a 320,9 mg.m ${ }^{-3}$. As espécies fitoplanctônicas dominantes identificadas foram Anabaena spiroides e Microcystis aeruginosa (Cyanophyceae). A temperatura da água foi de $27,8^{\circ} \mathrm{C}( \pm 0.88)$. O valor máximo de concentração de microcistinas foi de $0,23 \mu \mathrm{g} . \mathrm{L}^{-1}$. A concentração de chl- $a$, quando ocorreu a mortalidade em massa $\left(2,022 \mathrm{mg} \cdot \mathrm{m}^{-3}\right)$, e as lesões histopatológicas indicam que a mortalidade de animais foi devida a cianotoxinas.
\end{abstract}

Palavras-chave: reservatórios, eutrofização, cianobactérias, mortalidade em massa, aves aquáticas. 


\section{Introduction}

The central-northern region of Argentina has a wide surface covered with dams. In Córdoba Province these artificial lakes cover more than 15,000 ha. There are 6 reservoirs only in the Rio Tercero basin, with a surface of over 7,000 ha. The increase in the human population, together with intensive agronomic activity, enhances the eutrophication process and algal blooms, interfering in different water uses (Figueiredo et al., 2004). Over several decades, numerous papers have warned about the trophic status of the reservoirs in Rio Tercero basin, where algal blooms are very frequent, mainly Cyanophyceae and Dinophyceae (Bonetto et al, 1976.; Boltovskoy and Foggetta, 1985; Rodriguez, 2001; Mac Donagh et al., 2005).

The capacity of toxins production in some cianobacterial strains -cianotoxins- and their effect on the biota are well known. The genera Microcystis and Anabaena in particular are toxin-producers, which are compounds of potential risk because of their wide distribution all over the world and their well recognised toxicity (Perez et al., 2008). Neurotoxins and hepatotoxins production are among their most important effects, with the possibility of affecting a large number of animal species (Briand, et al., 2003; Vela et al., 2007; Stewart et al., 2008). In the case of recreational waters, the risk for human health is associated to the trophic status of the reservoirs, more precisely with Chl- $a$ concentration and algal density (Chorus et al., 1998).

Because of Cianobacterial characteristics, the environmental problems they produce, and their consequences for human health, continuous evaluation is necessary allowing the prediction of risks due to blooms formation (Forján Lozano et al., 2008). During March 2009, an algal bloom occurred in a reservoir from central Argentina, coinciding with the death of some animal species like two horses Equus caballus, a bovid Bos taurus, a "coipo" Myocastor coypus, and more than 60 wild birds, mainly "gallareta" Fulica sp. (Figure 1). Later on, the death of dogs (Canis familiaris) and "iguanas" (Tupinambis sp.) were observed. There are no records for this country of any case of similar characteristics.

The goal of this research was to establish a relationship between the animal deaths and bloom occurrence.

\subsection{Study area}

Piedras Moras reservoir (32 $12^{\circ} 27^{\prime \prime} \mathrm{S}$ e $64^{\circ} 16^{\prime} 29^{\prime \prime} \mathrm{W}$; 832 ha) is a multipurpose environment, and is part of a series of lakes belonging to the Rio Tercero basin (Córdoba Province, Argentina) (Figure 2). Its surface is 589 and 832 ha. for minimal and maximal level respectively. The reservoir is used for energy production, swellings moderation, water supply, fishing, recreation, water sports and irrigation.

\section{Material and Methods}

In situ variables were evaluated (temperature and transparency by means of the Secchi disk). Samples were taken in order to identify algal species, Chl- $a$ concentration (spectrophotometry) and toxins -total microcystines-

$64.329855 \mathrm{~W}$

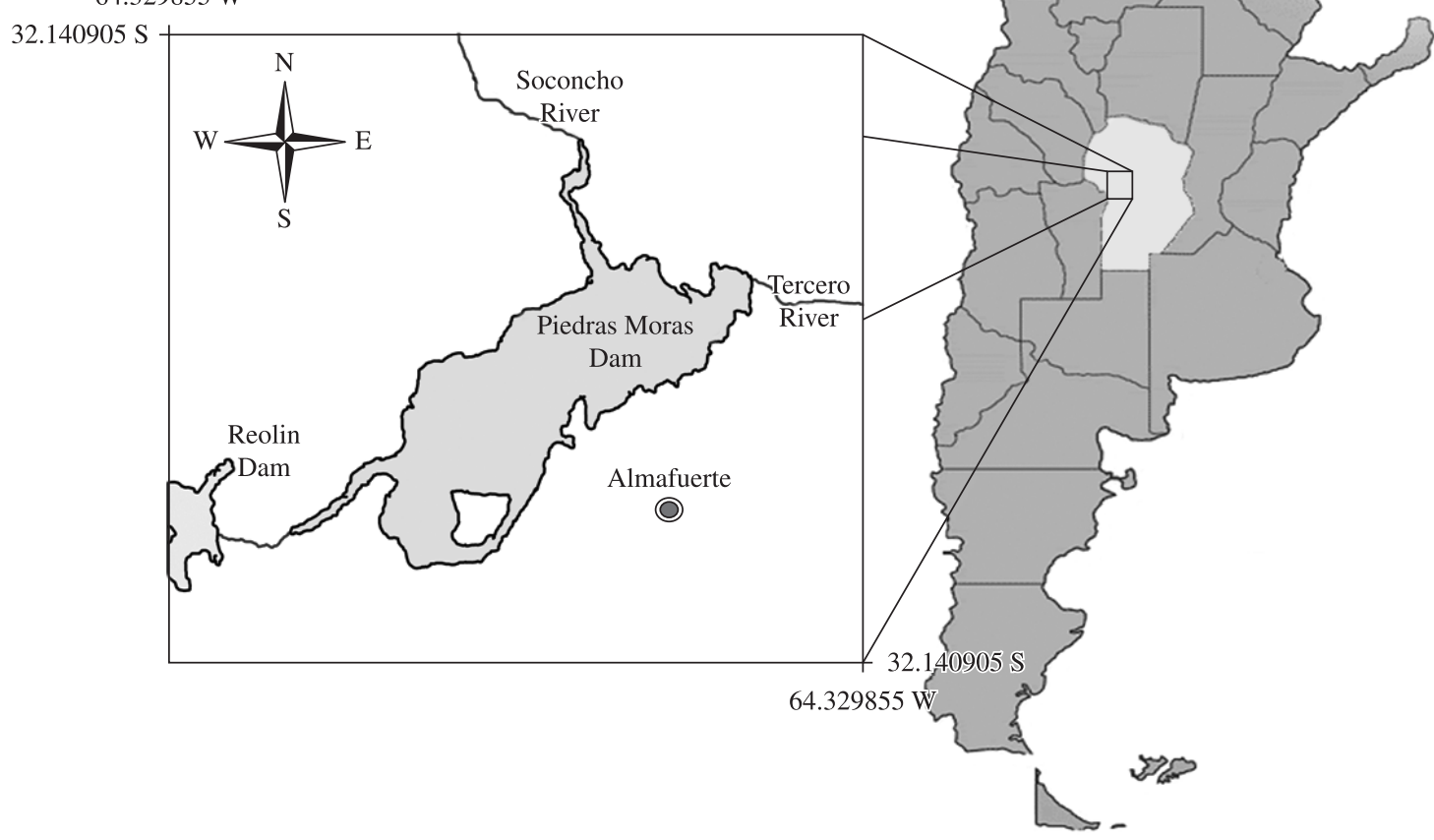

Figure 1. Geographical location of Piedras Moras reservoir (Argentina). 
(inmuno-enzymatic assay, ELISA). Samples were taken from the limnetic region, using a motor boat for that purpose. Sampling sites for measuring transparency and temperature were 14, 3 for toxins, and 5 for phytoplankton and Chl- $a$.

Samples of nervous tissue, liver and kidney for histopathology studies were obtained after capture and necropsy of several Fulica sp. corpses. These samples were kept in buffered formaline and were processed with conventional methodology for paraffin inclusion and hematoxiline-eosine staining

\section{Results}

A strong heterogenity in water transparency was observed, and "patches" of Potamogeton berteroanus distributed all along the lake, with Secchi disk minimal and medium values of 0.15 and $0.94 \mathrm{~m}$. Average Chl- $a$ concentration was $145.8 \mathrm{mg} . \mathrm{m}^{-3}$, reaching $2,022 \mathrm{mg} . \mathrm{m}^{-3}$ at the time of higher animal diseases. This effect was observed with the formation of floating algal masses and markings resembling green paint on the shores. Water temperature was $27.8^{\circ} \mathrm{C}$ (Table 1). Algal analysis showed a low species diversity, with predominance of Anabaena spiroides and Microcystis aeruginosa. Maximal value of total microcystines concentration was $0.23 \mu \mathrm{g} . \mathrm{L}^{-1}$.

The histopathology of Fulica sp., revealed intense changes in the parenchyma of several organs. Very important gliosis in the brain were presented, with neuronofagia and

Table 1. Records of water quality in Piedras Moras reservoir.

\begin{tabular}{lrcccc}
\hline \multicolumn{1}{c}{ Variable } & n & Ref. & Average & Minimal & Maximal \\
\hline Temperature & 14 & ${ }^{\circ} \mathrm{C}$ & 27.8 & 27.0 & 29.1 \\
Secchi disk & 14 & $\mathrm{~m}$ & 0.94 & 0.15 & 1.90 \\
Chl- $a$ & 5 & $\mathrm{mg} \cdot \mathrm{m}^{-3}$ & 145.8 & 9.0 & 320.9 \\
\hline
\end{tabular}

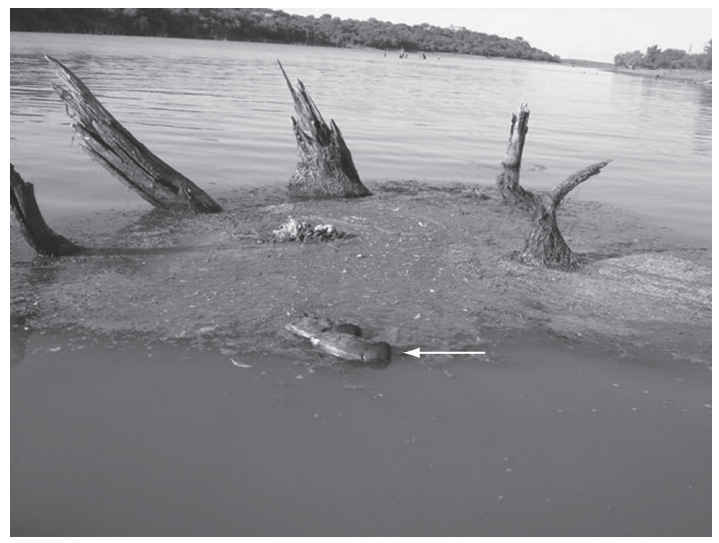

Figure 2. Dead specimens (Fulica sp.) at the entrance of the lake. satellitosis figures, as well as cytoplasmic tigrolisis and acidophilia. Marked degenerative changes in the neuropil were shown (Figure 3). Liver parenchyma showed intense signs of cell toxicity, with swelling and apparent nuclear changes of major cellular alteration. Severe bile pigment accumulation (toxic jaundice) in the hepatocytes cytoplasm was observed (Figure 4). Also, the renal parenchyma showed swelling of the epithelial cells of renal tubular epithelium and significant alterations of necrosis with large amounts of protein in the tubular lumen, like strong evidence of nephrotoxicity signs.

\section{Discussion}

Chl- $a$ concentration, compared to the record obtained at the time of mass mortality, strongly suggests that toxins (mainly anatoxines) reached high values, and that they most probably were the cause of animal deaths. These deaths are at least impossible to explain by other causes, being

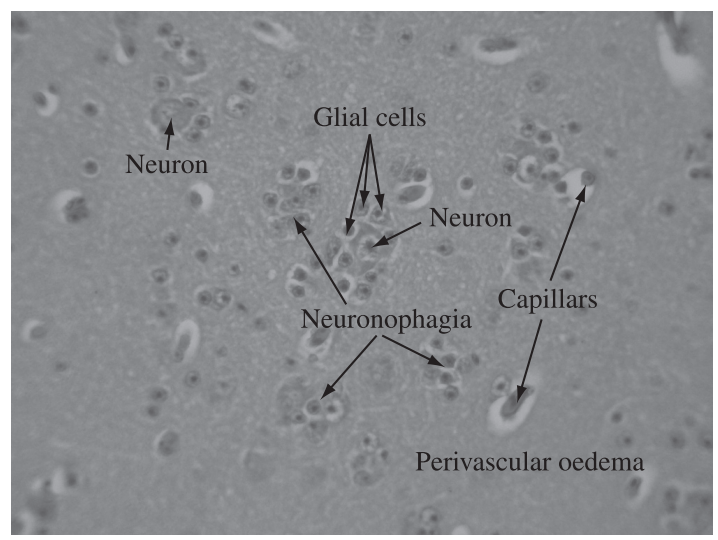

Figure 3. Brain tissue. Evident signs of neuronal degeneration and necrosis. Note intense satellitosis by glial cells around neurons and perivascular oedema. H/E $\times 1000$.

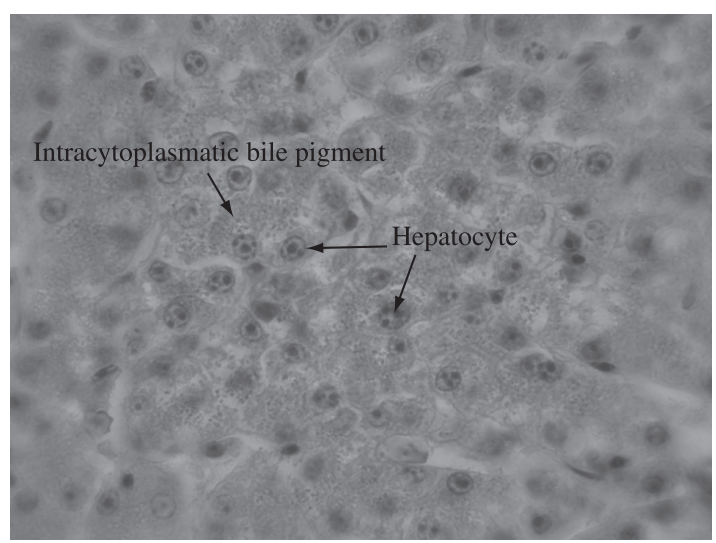

Figure 4. Liver tissue. Hepatocytes with intracytoplasmic bile pigment: Note nuclear changes, swelling and presence of severe bile pigment (jaundice) in the cytoplasm of hepatocytes. $\mathrm{H} / \mathrm{E} \times 1000$. 
all them very different organisms and occurring at places far from the lake. There are three kinds of neurotoxins: anatoxin a (ANTX-a), anatoxin a(S) (ANTX-s) and saxitoxin (SXT). It is also well known that anatoxins have a much more acute and lethal effect than microcystines, they can block post-synaptic depolarisation, acetilcolinesterase and sodium channels. These toxins are liberated into the water after cellular death and membrane hydrolysis of the cianobacteria, as happened in this case (Chorus et al., 1998).

Furthermore, injuries found in the liver and kidney of the birds days later showed the toxic action of microcystine. Although assessed total microcystines concentration was low, Chl- $a$ concentration during the peak of mortality was much higher, revealing that toxicity may vary in the same strain, in the same water body and even during the same bloom (De León, 2002).

According to Chorus and Bartram (1999) hepatotoxins in the world are more common than neurotoxins, as far as records for all continents show. Nevertheless, these results could occur because of the heterogeneous development of methodologies for the analysis of toxins and the bigger effort in standardisation methods to detect hepatotoxins. The most usually detected hepatotoxin is microcystine, which acts as an inhibitor of protein phosphatase 1 and 2A (Chorus and Bartram, 1999).

There are many reports indicating the death of several aquatic wild birds by means of the action of Microcystis and Anabaena, together with a variety of animals similar to those described here (Codd et al., 2005; Emiliani, M. and Emiliani, E., 1997; Chorus and Bartram, 1999). Briand et al. (2003) claim that integral and multidisciplinary approaches in massive domestic and wild animal death events by cianobacteria should consider also macro- and microscopic pathologic studies in order to achieve a proper diagnosis.

Our histopathology studies on Fulica sp. are coincident with the reports of other researchers, who observe the same kind of injuries in the liver, nervous system and kidneys of different animal species (Stewart et al. 2008, Tyagi et al., 2006; Zurawell et al., 2005). The injuries on the nervous system support this hypothesis, and are related with the signs showed by dying birds such as loss of coordination and flying difficulties.

Cianobacterial blooms produce important sanitary and aesthetic damage on several water bodies for human uses such as recreation, bathing, water source for consumption, among others (De León, 2002). Even when a large amount of reservoirs in the centre and north of Argentina, including those of Cordoba Province, are characterised for their high trophic status (Pizzolon et al., 1999; Rodriguez et al., 2007), the results of the Chl- $a$ concentration and the number of cells. $\mathrm{mL}^{-1}$ during last March did not allow the recreational use of Piedras Moras Lake, in that they exceeded the Level Guide 2, according to the Directives for Security of Recreational Waters of the WHO for 2004 (Chorus et al., 1998).
Several causes may have contributed to the high trophic level of the lake, such as high temperature and low rain records during February and March, together with a larger organic nutrient input from increased agricultural practices on the draining area (Rodriguez, 2001).

Furthermore, the anthropocoria in the last years of a planctivorous fish (Mancini et al., 2006) and lake characteristics, as being the last one of the series (Calcagno, 1996), may also favour the process.

According to limnology antecedents of Lake Piedras Moras, its trophic conditions oscillate between mesotrophic to eutrophic, but with a marked dynamics: for some occasions water transparency was over $5 \mathrm{~m}$ (Secchi disk) (Rodriguez, 2001; Mancini et al., 2008). Chl- $a$ concentration, low water transparency and massive cianobacterial development reported in this study suggest a high trophic level (Lampert and Sommer, 1997; Straskraba and Tundisi, 2000).

Integral and periodical monitoring is recommended, in order to provide an early alert about the danger of similar incidents and the potential risks for human and animal health.

Acknowledgements - To the Municipality of Almafuerte (Córdoba, Argentina). To Nelci Schleef (UNRC), Edgar Taricco and Sebastian Lopez, for their collaboration with this work. This paper is part of the collaboration of International Institute of Ecology (Brasil) and University of Río Cuarto (Argentina).

\section{References}

BOLTOVSKOY, A. and FOGGETTA, M., 1985. Limnología física del embalse Río Tercero (térmica, hidrológica y derivaciones biológicas). Biología Acuática, vol. 7.

BONETTO, A., DI PERSIA, D., MAGLIANESI, R. and CORIGLIANO, M., 1976. Caracteres limnológicos de algunos lagos eutróficos de embalses de la región central de Argentina. Ecosur, vol. 3, no. 5, p. 47-120.

BRIAND, J., JACQUET, S., BERNARD, C. and HUMBERT, J., 2003. Health hazards for terrestrial vertebrales form toxic cyanobacteria in surface water ecosystems. Veterinay Research, vol. 34, p. 361-377.

CALCAGNO, A., 1996. Programa Nacional de agua potable y alcantarillado cloacal. Córdoba: Coop. de Servicios Públicos Almafuerte Ltda. 103 p

CHORUS, I. and BARTRAM, J., 1999. Toxic cyanobacteria in water. New York: WHO.

CHORUS, I., FALCONER, I., SALAS, H. and BARTRAM, J., 1998. Riesgo a la salud causados por cianobacterias y algas de agua dulce en aguas recreacionales - AIDIS. Asociación Peruana de Ingenieria Sanitaria y Ambiental. Lima: Apis, 30 p.

CODD, G., MORRISON, L. and METCALF, J., 2005. Cyanobacterial toxins: risk management for health protection. Toxicology and Applied Pharmacology, vol. 203, p. 264-272.

DE LEÓN, L., 2002. Floraciones de cianobacterias en aguas continentales del Uruguay: causas y consecuencias: en perfil ambiental del Uruguay. Montevideo: Nordan-Comunidad. p. 28-37. 
EMILIANI, M. and EMILIANI, F., 1997. Mortandad de ganado y aves silvestres asociada con una floración de Anabaena spiroides Kleb. Natura Neotropicalis, vol. 28, no. 2, p. 150-157.

FIGUEIREDO, D., AZEITERO, U., ESTEVES, S., GONCALVES, F. and PEREIRA., M., 2004. Microcystin-producing blooms- a serious global public health isuue. Ecotoxicology and Environmental Safety, vol. 59, p. 151-163.

FORJÁN LOZANO, E., DOMINGUEZ VARGAS, M., VILCHES LOBATO, C., MIGUEL, R., COSTA, C. and REIS, M., 2008. Cianoalerta: estrategia para predecir el desarrollo de cianobacterias tóxicas en embalses. Ecosistemas, vol. 17, no. 1, p. 37-45.

LAMPERT, W. and SOMMER, U., 1997. Limnoecology: the ecology of lakes and streams. Oxford: Oxford University Press. $382 \mathrm{p}$.

MAC DONAGH, M., CASCO, M. and CLAPS, M., 2005. Colonization of a Neotropical Reservoir (Córdoba, Argentina) by Ceratium hirundinella (O.F. Muller). Annales de Limnologie, vol. 41, no. 4, p. 291-299.

MANCINI, M., HARO, JG. and GROSMAN, F., 2006. Primer registro del bagarito Parapimelodus valenciennes (Lutken, 1874) (Siluriformes, Pimelodidae) para la provincia de Córdoba, Argentina. Natura Neotropicalis, vol. 37, no. 1-2, p. 77-81.

MANCINI, M., RODRIGUEZ, C., BONANSEA, M., ASTORECA, A., BAGNIS, G., ROCHA, C. and DALCERO, A., 2008. Saprolegniasis en poblaciones silvestres de Astyanax eigenmanniorum y A. fasciatus (Pisces, Characidae) de Argentina. Revista Brasileira de Medicina Veterinaria, vol. 30, no. 2, p. 115-122.

PÉREZ, D., SORACI, A. and TAPIA, M., 2008. Cianobacterias y cianotoxinas: rol de las microcistinas en la salud human y animal y su detección en muestras de agua. Analecta Veterinaria, vol. 28 , no. 1 , p. $48-56$.
PIZZOLON, L., TRACANNA, B., PROSPERI, C. and GUERRERO, M., 1999 Cyanobacterial blooms in Argentinean inland waters. Lakes \& Reservoirs: Research and Manegement, vol. 4, p. 101-105.

RODRIGUEZ, C., 2001. Variaciones temporales y espaciales en la calidad del agua del embalse Piedras Moras. Córdoba: Universidad Nacional de Córdoba. 105 p. [Tese de Doutorado].

RODRIGUEZ, C., BONANSEA, M., BONATTO, F., REYNOSO, V., PROSPERI, C., MANCINI, M. and LEDESMA, C., 2007. Remote sensing-GIS to predict on the risk of eutrophication in aquatic systems. In Space Technology for E-Health. Space Technology based tele-health project initiatives in Latin America and the Caribbean. New York: United Nations. p. 28-30.

STEWART, I., SEAWRIGHT, A. and SHAW, G., 2008. Cyanobacterial poisoning in livestock, wild mammals and birds - an overview. In KENNETH HUDNELL, H. (Ed.). Cyanobacterial harmful algal blooms: state of the Science and Research Needs. Springer. Chapter 28, p. 613-637.

STRASKRABA, M. and TUNDISI, JG., 2000. Directrizes para o gerenciamiento de lagos: gerenciamento de qualidade da agua de represas. São Carlos: ILEC, IIE. 300 p. vol. 9.

TYAGI, M., SINGH, D., KUMAR, A., JHA, P., SINHA, R. and KUMAR, A. 2006. Hepatotoxicity of Microcystis aeruginosa strains growing as blooms in certain eutrophic ponds. EXCLI Journal, no. 5, p. 66-78.

VELA, L., SEVILLA, E., MARTÍN, B., PELLICER, S., BES, M., FILLAT, M., PELEATO, M., 2007. Las microcistinas. Revista Real Academia de Ciencias, vol. 62, p. 135-146.

ZURAWELL, R., CHEN, H., BURKE, J. and PREPAS, E., 2005. Hepatoxic Cyanobacteria: a review of the biological importante of microcystins in fresh water environments. Journal of Toxicology and Environmental Health, vol. 8, p. 1-37. 